\title{
PENGEMBANGAN PERANGKAT PEMBELAJARAN IPA BERBASIS KOOPERATIF UNTUK MELATIH LITERASI SAINS SISWA PADA MATERI FOTOSINTESIS DAN RESPIRASI
}

\author{
${ }^{1)}$ Asri Fahmiati, ${ }^{2)}$ Endang Susantini, ${ }^{3)}$ Fida Rachmadiati \\ ${ }^{1)}$ Mahasiswa Program Studi Pendidikan Sains, Program Pascasarjana Universitas Negeri Surabaya, \\ ${ }^{2}$ Dosen Program Studi Pendidikan Sains, Program Pascasarjana Universitas Negeri Surabaya \\ ${ }^{3)}$ Dosen Program Studi Pendidikan Sains, Program Pascasarjana Universitas Negeri Surabaya \\ e-mail: asrifahmiati@gmail.com
}

\begin{abstract}
This research aimed for producing a feasible learning materials to facilitate junior high school science literacy. The development of the learning material used the 4D model and tested in class VII SMP Al Hikmah Surabaya even semester in academic year of 2016/2017. The research took place by applying the 4D model. The data collections used were validation, observation, test, and questionnaires methods. The Data were analyzed using quantitative descriptive analysis. The results showed that: (1) a valid learning materials developed; (2) the learning process took place well; (3) the science literacy of students had been facilitated and get N-Gain score 0.84 , hight category; (4) the students responded positively towards learning. Based on the above results, it can be concluded that the Cooperative Learning model developed was feasible used to facilitate science literacy student.
\end{abstract}

Keywords: Learning Materials, Cooperative Learning, Science Literacy

Abstrak: Penelitian ini bertujuan untuk menghasilkan perangkat pembelajaran IPA yang layak untuk melatih literasi siswa Sekolah Menengah Pertama. Pengembangan perangkat menggunakan model pembelajaran 4D, dan diujicobakan di kelas VII SMP Al Hikmah Surabaya tahun ajaran 2016/2017. Pembelajaran ini dilaksanakan dengan menerapkan perangkat pembelajaran model Cooperative Learning. Pengumpulan data menggunakan metode validasi, observasi, tes dan angket. Teknik analisis data menggunakan analisis deskriptif kuantitatif. Hasil analisis data penelitian menunjukkan bahwa: (1) perangkat pembelajaran yang dikembangkan sangat valid; (2) pembelajaran terlaksana dengan kategori baik; (3) perangkat yang disusun dapat melatih literasi sains siswa sehingga mendapatkan N-Gain 0,84 dengan kategori tinggi; (4) Siswa memberikan respons positif terhadap pembelajaran. Berdasarkan hasil penelitian tersebut, dapat disimpulkan bahwa perangkat yang dikembangkan dengan model Cooperative Learning layak digunakan untuk melatih literasi sains siswa.

Kata Kunci: Perangkat Pembelajaran, Model Cooperative Learning, Literasi Sains.

\section{PENDahuluan}

Abad ke-21 merupakan abad globalisasi yang penuh tantangan. Negara-negara di dunia semakin giat berpacu untuk memenangkan era persaingan global yang ditandai dengan kemajuan sains dan teknologi. Peningkatan kemampuan dan pemahaman terhadap sains dan teknologi merupakan kunci kemajuan suatu bangsa. Tak dapat diragukan lagi, penerapan atas sains dan teknologi telah menunjukkan perubahan yang revolusioner di banyak negara. Seiring dengan berkembangnya zaman, tehnologi dan informasi yang pesat, maka setiap orang harus dapat memahami lingkungan hidup, kesehatan, dan masalah lainnya yang dihadapi masyarakat modern. Oleh karena itu literasi sains menjadi keharusan bagi setiap orang. Literasi sains menjadi sangat penting bagi seseorang karena maju mundurnya suatu bangsa salah satunya ditentukan oleh kualitas sumber daya manusia yang memiliki literasi terhadap sains dan teknologi (OECD, 2013).

Berdasarkan penelitian tentang kemampuan literasi sains siswa dalam skala internasional diselenggarakan oleh Organzation for Economic Cooperation and Development (OECD) melalui Programme for International Student Assesment (PISA) bahwa literasi sains perlu dikembangkan karena literasi sains di Indonesia masih tergolong rendah hal ini ditunjukkan pada tahun 2009, Indonesia menduduki peringkat 60 dari 65 negara yang terlibat dalam PISA untuk bidang sains. Kemampuan literasi sains siswa Indonesia dari tahun 2003-2012 berdasarkan penilaian PISA menduduki peringkat 64 dari 65 negara (OECD, 2013). 
Salah satu model pembelajaran yang mendukung literasi sains dan perkembangan pendidikan abad ke-21 serta telah digariskan pemerintah Indonesia dalam kurikulum 2013 adalah pembelajaran yang inovatif dan kooperatif. Slavin (2007), menjelaskan keunggulan pembelajaran kooperatif, pertama: menggalakkan siswa berinteraksi secara aktif dan positif dalam kelompok. Proses pembelajaran dapat menanamkan dan melatih aspek-aspek soft skills, antara lain saling memiliki (sense of belonging), rasa tanggung jawab (sense of responsibility), kejujuran, dan adaptif terhadap berbagai situasi (Huda, 2011).

Keunggulan penggunaan model kooperatif kedua: akan merealisasikan kebutuhan siswa dalam belajar, berpikir, memecahkan masalah dan mengintegrasikan pengetahuan dan keterampilan (Slavin, 2007). Keunggulan kedua ini akan dapat menjadi sarana untuk melatihkan keterampilan literasi sain yang meliputi: mengidentifikasi isu ilmiah, menggunakan bukti ilmiah dan menjelaskan fenomena ilmiah.

Model kooperatif yang terdiri dari berbagai tipe dapat dipilih yang sesuai kemudian digunakan secara bervariasi dari berbagai tipe yang ada sehingga dapat mencapai tujuan penelitian yaitu terlatihnya keterampilan literasi sains siswa. Tipe yang akan digunakan dalam penelitian ini adalah STAD (Student Teams Achievement Divisions) dan CIRC (Cooperative, Integrated, Reading, and Compisition). Tipe STAD dipilih karena dalam sintaksnya terdapat pemberian informasi, hal ini dibutuhkan siswa pada tahap awal memahami literasi sains. Tipe CIRC dipilih karena aktivitas siswa untuk memahami artikel berkaitan dengan issu dan fenomena ilmiah di sekitar siswa.

Holbrook \& Milia (2009) menyatakan literasi sains berarti penghargaan pada ilmu pengetahuan dengan cara meningkatkan komponen-komponen belajar dalam diri agar dapat memberi kontribusi pada lingkungan sosial. Berdasarkan pernyataan diatas literasi sains memiliki arti luas, setiap kalangan umur dapat memberikan kontribusi dalam mengartikan literasi sains dan memberikan kontribusi terhadap teknologi berdasarkan tingkat pemahaman yang dimilikinya.

Komponen literasi sains harus diterjemahkan menjadi indikator-indikator sehingga dapat mengetahui dan mengukur kemampuan literatur sains siswa. Pada penelitian ini diterapkan empat aspek literasi sains, yaitu aspek pengetahuan ilmiah (scientific content), aspek konteks (scientific context), aspek keterampilan (scientific processes) dan sikap siswa terhadap isu-isu sains (Beybee, 1995).

Tiga aspek dari komponen keterampilan sains berikut: (1) Mengidentifikasi pertanyaan ilimiah. Ciri hakiki pertanyaan ilmiah yang membedakannya dari bentuk lain pertanyaan adalah pertanyaan ilmiah meminta jawaban berlandaskan bukti ilmiah. Termasuk di dalamnya mengenal pertanyaan yang mungkin diselidiki secara ilmiah dalam situasi yang diberikan, mengidentifikasi kata-kata kunci untuk mencari informasi ilmiah tentang suatu topik yang diberikan. (2) Menjelaskan fenomena secara ilmiah. Kompetensi ini mencakup mendeskripsikan atau menafsirkan fenomena, memprediksi perubahan. Kompetensi ini melibatkan pengenalan dan identifikasi deskripsi, eksplanasi dan prediksi yang sesuai. (3) Menggunakan bukti ilmiah. Kompetensi ini menuntut peserta didik memaknai temuan ilmiah sebagai bukti untuk suatu kesimpulan. Kompetensi ini dinilai dengan cara-cara berikut: a)Penilaian peserta terhadap informasi ilmiah b)Menarik kesimpulan berdasarkan bukti ilmiah c) Memilih dari alternatif-alternatif kesimpulan yang terkait bukti yang diberikan d) Memberikan alasan untuk setuju atau menolak kesimpulan yang ditarik dari data yang tersedia e)Mengidentifikasi asumsi-asumsi yang dibuat dalam mencapai kesimpulan f) Membuat refleksi berdasarkan implikasi sosial dari kesimpulan ilmiah. (OECD 2009).

Materi fotosintesis dan respirasi merupakan materi pembelajaran yang berkaitan erat dengan fenomena yang sering terjadi di lingkungan sekitar kita, diantaranya fotosintesis yang dapat mengatasi pencemaran lingkungan dan globar warming yang terjadi di dunia dalam skala luas dan terjadi di Surabaya dalam skala lokal karena menghasilkan oksigen. Masalah dan pemecahannya sangat penting untuk dilatihkan, agar siswa memiliki pengetahuan dan pemahaman tentang upaya pengurangan resiko dan dampak yang ditimbulkan, serta tindakan yang dapat dilakukan oleh siswa sebagai alternatif pemecahan masalah.

Berdasarkan uraian di atas maka tujuan penelitian ini adalah untuk mengembangkan perangkat pembelajaran berbasis kooperatif untuk 
melatih literasi sains siswa pada materi fotosintesis dan respirasi.

\section{METODE}

Penelitian ini termasuk penelitian pengembangan yang mengembangkan perangkat pembelajaran model Cooperative learning untuk melatih literasi sains siswa yang meliputi: Rencana Pelaksanaan Pembelajaran (RPP), Lembar Kegiatan Siswa (LKS), Buku Ajar Siswa (BAS), serta lembar penilaian test literasi sains.. Penelitian ini dilakukan di SMP Al Hikmah Surabaya. Subyek penelitian ini adalah perangkat pembelajaran IPA model Cooperative Learning yang dikembangkan dan diujicobakan pada 30 siswa kelas VII.

Teknik pengumpulan data menggunakan metode observasi, tes, dan angket. Data pada penelitian ini adalah data pengamatan keterlaksanaan pembelajaran, data berupa hasil Post test literasi sains serta data angket respon siswa. Teknik analisis data berupa analisis data validasi, analisis keterlaksanaan RPP, hasil postest literasi sains dan respon siswa. Rancangan pengembangan perangkat pembelajaran dalam penelitian ini mengacu pada model 4D yang dimodifikasi sesuai dengan kebutuhan peneliti Proses pengembangan tersebut terdiri atas tahapan sebagai berikut, yaitu: menganalisis $\mathrm{KI}$ dan $\mathrm{KD}$, analisis siswa, analisis pembelajaran, merumuskan indikator, menyusun tes acuan patokan, memilih strategi pembelajaran, pengembangan perangkat pembelajaran, validasi perangkat dan revisi, uji coba.

Variabel Penelitiannya ada 3 yaitu validitas perangkat pembelajaran, variabel kepraktisan perangkat pembelajaran dan keefektifan perangkat pembelajaran. Tujuan validasi perangkat pembelajaran adalah untuk mendapatkan masukan, perbaikan perangkat dan menghasilkan perangkat pembelajaraan yang layak diujicobakan. Deskripsi validitas perangkat ditinjau dari hasil validasi dua pakar pembelajaran. Variabel Kepraktisan Perangkat Pembelajaran didasarkan pada hasil pengamatan dua pengamat terhadap keterlaksanaan RPP dan sintaks Cooperative Learning selama proses pembelajaran. Observasi atau pengamatan dilakukan untuk mengumpulkan data penelitian yang berkenaan dengan sikap dan perilaku/kinerja. Keterlaksanaan RPP diukur melalui pengamatan yang dilakukan oleh dua orang guru bidang studi IPA di SMP Al Hikmah yang bertindak sebagai pengamat (observer) selama proses pembelajaran.

Variabel keefektifan perangkat pembelajaran ditinjau dari dua variabel yaitu hasil tes Literasi sains siswa dan respon siswa. Hasil tes literasi sains siswa diukur melalui tes yang dilaksanakan sebelum dan setelah proses pembelajaran (sebagai pretest dan posttest). Respon siswa diukur dengan angket respon siswa yang diberikan setelah rangkaian proses pembelajaran selesai.

Instrumen yang digunakan dalam penelitian adalah: 1) Lembar Validasi Perangkat Pembelajaran: lembar yang digunakan sebagai acuan penentuan predikat/kategori perangkat pembelajaran oleh validator. Lembar validasi disertai skor penilaian dan saran terhadap perangkat pembelajaran yang dikembangkan. 2) Lembar Pengamatan Kepraktisan Perangkat Pembelajaran: berupa lembar keterlaksanaan RPP dalam proses pembelajaran. Pengisian lembar pengamatan dilakukan dengan memberi tanda cek $(\sqrt{ })$ pada kolom yang sesuai dengan tahapan pembelajaran, serta memberi skor dari rentang 1-4 yang sesuai. Penilaian kualitas keterlaksanaan RPP ditentukan dengan menghitung rata-rata skor penilaian yang diberikan dua orang pengamat. Selain itu dilakukan perhitungan reliabilitas instrumen untuk menentukan baik tidaknya instrumen yang dikembangkan dengan rumus sebagai berikut:

$$
\mathbf{R}=\left[\frac{A}{D+A}\right] \times 100 \%
$$

Keterangan:

$\mathrm{R}=$ Reliabilitas instrumen (percentage agreement)

$\mathrm{A}=$ Frekuensi kecocokan antar kedua penilai

$\mathrm{D}=$ frekuensi ketidakcocokan antar kedua penilai

Instrumen penilaian perangkat dikatakan reliabel jika nilainya $\geq 75 \%$ (Borich, 2015).

Instrumen yang ketiga yaitu lembar keefektifan penerapan pembelajaran: berupa lembar soal Tes Literasi Sains terdiri dari 25 soal pilihan ganda dengan sebaran tingkat kognitif C1 - C5. Soal tersebut digunakan sebagai soal pretest dan posttest.

Teknik analisis data dalam penelitian ini menggunakan deskriptif kuantitatif dan kualitatif. Validitas perangkat pembelajaran dikatakan valid jika percentage of agreement $\geq 75 \%$. Selisih antara nilai 
pretest dan posttest nilai tes pemahaman konsep dilakukan analisis statistik inferensial melalui analisis $N$-gain. Untuk membandingkan rata-rata dari dua variabel (pretest dan posttest).

\section{HASIL DAN PEMBAHASAN}

Hasil dari penelitian ini adalah perangkat pembelajaran yang meiputi: rencana pelaksanaan pembelajaran(RPP), buku ajar siswa (BAS), lembar kegiatan siswa (LKS) dan lembar pengamatan sikap, instrumen tes Literasi sains.

Hasil validasi perangkat pembelajaran oleh dua orang pakar, yaitu Dosen Universitas Negeri Surabaya tertera pada Tabel 1 berikut:

Tabel 1. Hasil Validasi Perangkat Pembelajaran

\begin{tabular}{|c|c|c|c|}
\hline No & Jenis perangkat & Kategori & $\mathbf{R}(\mathbf{\%})$ \\
\hline 1 & $\begin{array}{c}\text { Rencana Pelaksanaan } \\
\text { Pembelajaran }\end{array}$ & Sangat valid & 97,56 \\
\hline 2 & Lembar Kegiatan Siswa & valid & 88,13 \\
\hline 3 & Buku Ajar Siswa & valid & 92,53 \\
\hline 4 & Lembar Pengamatan Sikap & Sangat valid & 92,86 \\
\hline 5 & $\begin{array}{c}\text { Instrumen Tes Literasi } \\
\text { Sains }\end{array}$ & Sangat valid & 91,50 \\
\hline
\end{tabular}

Keterangan: $\mathrm{R}:$ Percentage of Agreement

Berdasarkan Tabel 1 di atas dapat dimaknai bahwa perangkat pembelajaran yang terdiri dari RPP, LKS, BAS, lembar pengamatan sikap, instrumen tes Literasi sains dianggap baik dan layak untuk digunakan.

Kepraktisan perangkat pembelajaran ditinjau dari keterlaksanaan langkah-langkah pembelajaran Cooperative Learning yang diskenariokan dalam RPP seperti tertera pada Tabel 2 berikut:

Tabel 2. Hasil Pengamatan Keterlaksanaan RPP

\begin{tabular}{|c|c|c|c|c|c|c|}
\hline Aspek yang & \multicolumn{2}{|c|}{ Pert.1 } & \multicolumn{2}{c|}{ Pert.2 } & \multicolumn{2}{c|}{ Rata-rata } \\
\cline { 2 - 7 } diamati & S & P & S & P & S & P \\
\hline $\begin{array}{c}\text { Penyampaian } \\
\text { tujuan } \\
\text { pembelajaran }\end{array}$ & 4,00 & $\mathrm{SB}$ & 4,00 & $\mathrm{SB}$ & 4,00 & $\mathrm{SB}$ \\
\hline $\begin{array}{c}\text { Penyajian } \\
\text { informasi }\end{array}$ & 4,00 & $\mathrm{SB}$ & 4,00 & $\mathrm{SB}$ & 4,00 & $\mathrm{SB}$ \\
\hline $\begin{array}{c}\text { Pembagian } \\
\text { kelompok }\end{array}$ & 3,50 & $\mathrm{SB}$ & 4,00 & $\mathrm{SB}$ & 3,83 & $\mathrm{SB}$ \\
\hline $\begin{array}{c}\text { Membimbing } \\
\text { belajar }\end{array}$ & 3,50 & $\mathrm{SB}$ & 4,00 & $\mathrm{SB}$ & 3,83 & $\mathrm{SB}$ \\
\hline Evaluasi/tes & 3,00 & $\mathrm{~B}$ & 4,00 & $\mathrm{SB}$ & 3,67 & $\mathrm{~B}$ \\
\hline Penghargaan & 3,00 & $\mathrm{~B}$ & 4,00 & $\mathrm{SB}$ & 3,67 & $\mathrm{~B}$ \\
\hline Penutup & 3,40 & $\mathrm{~B}$ & 3,60 & $\mathrm{~B}$ & 3,50 & $\mathrm{~B}$ \\
\hline $\begin{array}{c}\text { Pengelolaan } \\
\text { waktu }\end{array}$ & 3,50 & $\mathrm{~B}$ & 3,50 & $\mathrm{~B}$ & 3,50 & $\mathrm{~B}$ \\
\hline
\end{tabular}

\begin{tabular}{|c|c|c|c|c|c|c|}
\hline Aspek yang & \multicolumn{2}{|c|}{ Pert.1 } & \multicolumn{2}{c|}{ Pert.2 } & \multicolumn{2}{c|}{ Rata-rata } \\
\cline { 2 - 6 } diamati & S & P & S & P & S & P \\
\hline $\begin{array}{c}\text { Suaasana } \\
\text { Kelas }\end{array}$ & 3,80 & SB & 3,80 & SB & 3,80 & SB \\
\hline
\end{tabular}

Keterangan. S: skor; P: predikat; B: baik; SB: sangat baik.

Berdasarkan Tabel 2 dapat dimaknai bahwa fase-fase pembelajaran Cooperative Learning dapat terlaksana dengan baik. Pengamatan keterlaksanaan penggunaan perangkat pembelajaran dilakukan oleh dua orang pengamat yang mencakup 9 tahapan, yaitu kegiatan penyampaian tujuan pembelajaran, penyampaian informasi, pembentukan kelompok, pembimbingan belajar, pemberian evaluasi/tes, pemberian penghargaan, penutup, pengelolaan waktu, dan suasana Kelas pada saat pembelajaran berlangsung. Pengamatan keterlaksanaan RPP model Cooperative Learning pada penelitian ini dilakukan selama 3 kali pertemuan yang merupakan implementasi dari RPP pertemuan ke-1 dan RPP pertemuan ke-2 dan ke-3. Berdasarkan analisis data hasil pengamatan keterlaksanaan RPP dapat diketahui bahwa seluruh tahapan berkategori sangat baik, kecuali pada tahapan pengelolaan waktu berkategori baik. Rata-rata percentage of agreement dari keterlaksanaan RPP sebesar 94,02\% sehingga dapat dikatakan bahwa pembelajaran terlaksana dengan baik.

Pada kegiatan pendahuluan, lebih menekankan pada kegiatan motivasi untuk menarik perhatian dan antusiasme siswa terhadap pembelajaran. Pada tahapan ini siswa melakukan kegiatan pengamatan terhadap video pembelajaran tentang keajaiban sinar matahari dan penggalian sejumlah pertanyaaan untuk menarik perhatian dan rasa ingin tahu siswa pada kegiatan pembelajaran selanjutnya.

Tahapan berikutnya adalah kegiatan inti, yaitu siswa dilibatkan dalam aktivitas mengamati kembali fenomena atau fakta-fakta menarik yang terjadi di lingkungan sekitar yang berhubungan dengan fotosintesis, khususnya proses menghasilkan karbohidrat dan oksigen melalui percobaan dengan menggunakan LKS 1 : Zat apakah yang dihasilkan dalam fotosintesis? LKS 2: Respirasi pada Kecambah dan LKS 3: Zat Apakah yang dihasilkan pada Respirasi? Kegiatan ini dapat menarik minat dan rasa ingin tahu siswa untuk mengajukan pertanyaan dan mengeksplorasi masalah. Fakta-fakta lainnya yang membuat siswa tertarik untuk belajar materi 
fotosintesis yaitu karena fenomena ini sering terjadi di lingkungan sekitar tempat tinggal siswa misalnya proses pembuatan berbagai macam tepung, fermentasi pada tape.

Pada kegiatan pembelajaran, siswa diorganisasikan dalam beberapa kelompok untuk memudahkan mengumpulkan informasi dan data-data dalam menyelesaikan permasalahan yang disajikan dan saat mengerjakan LKS. Sehingga dapat melibatkan siswa secara aktif berinteraksi dengan teman sekelompoknya dalam mencari jawaban dan penyelesaian permasalahan dalam LKS. Keseluruhan fase Cooperative Learning yang masuk pada kegiatan inti memfasilitasi siswa untuk mendapatkan pembelajaran yang lebih bermakna sehingga dapat meningkatkan hasil belajar dan melatih literasi sains siswa.

Kegiatan penutup dilakukan dengan menyimpulkan hasil pembelajaran bersama-sama antara guru dengan siswa, mengingatkan siswa untuk selalu bersyukur, memberi penghargaan pada hasil kerja seluruh kelompok, serta memberitahukan kepada siswa tentang materi dan kegiatan yang akan dilakukan pada pertemuan berikutnya.

Pengelolaan waktu di awal pertemuan memerlukan waktu yang lebih pada setiap tahap pembelajaran dari waktu yang telah direncanakan dikarenakan siswa masih belum terbiasa dengan model pembelajaran yang diterapkan dan penulisan laporan hasil penyelidikan. Namun, setelah diperbaiki pada pertemuan selanjutnya lebih baik dan dapat memanfaatkan waktu dengan efektif. Pengamatan kegiatan belajar mengajar (KBM) diperoleh kategori sangat baik. Hal ini menunjukkan siswa dan guru antusias dalam pelaksanaan kegiatan pembelajaran model Cooperative Learning.

Keefektifan perangkat pembelajaran dapat ditinjau dari hasil tes literasi sains siswa. Tes Literasi sains yang telah diujicobakan meliputi: aspek pengetahuan, dan aspek keterampilan literasi. Sikap literasi diamati oleh peneliti yang sekaligus sebagai pengajar dan dituliskan dalam jurnal siswa.

Aspek Pengetahuan/ conten literasi, Nilai postest rata-ratanya adalah 82,29 meningkat dibandingkan nilai pretes yaitu 40,24. Peningkatan tersebut dapat juga diketahui melalui hasil perolehan skor $N$-gain yaitu berkisar antara 0,74 - 1,00 dimana kategori $\mathrm{N}$-gain tinggi lebih mendominasi. Data ketuntasan pretest dan posttest yang telah dipaparkan di atas menunjukkan adanya peningkatan pemahaman dan pengetahuan siswa tentang materi fotosintesis dan respirasi.

Tes aspek pengetahuan dikatakan baik atau tidak, maka digunakan analisis sensitivitas butir soal. Sensitivitas butir soal yang telah dianalisis menunjukkan perolehan skor dengan rentang 0,30 0,77 dengan kategori sensitif (Gronlund, 1995). Hasil yang diperoleh tersebut menunjukkan bahwa tiap butir soal yang telah dikembangkan memiliki kepekaan yang cukup terhadap efek pembelajaran yang diberikan. Hal ini menunjukkan bahwa peningkatan aspek pengetahuan siswa merupakan efek dari pelaksanaan pembelajaran dengan menggunakan perangkat pembelajaran model Cooperative Learning yang telah dikembangkan sejalan dengan penelitian Arisman (2015), Penerapkan model pembelajaran kooperatif tipe STAD mampu meningkatkan literasi sains.

Aspek Keterampilan Literasi Sains/conteks literasi yang dilatihkan ada 3 yaitu: (1) mengidentifikasi isu; (2) menggunakan bukti ilmiah; (3) menjelaskan fenomena ilmiah. Indikator masingmasing aspek di atas adalah sebagai yang tertera pada penjelasan di awal teks.

Nilai pretes siswa diperoleh melalui penilaian secara tertulis yaitu untuk 3 indikator literasi sain adalah 42,15 sedangkan postesnya adalah 90,33. Peningkatan tersebut dapat juga diketahui melalui hasil perolehan skor $N$-gain yaitu berkisar antara 0,76 - 0,90 dimana kategori $N$-gain tinggi lebih mendominasi. Nilai juga diambil saat siswa berdiskusi yang dengan fotosintesis dan lingkungan dari artikel yang telah dicari oleh siswa sebagai tugas mandiri. Aspek yang dinilai adalah kebenaran menjawab soal, isi artikel yang diperoleh, sistematika presentasi, qualitas menjawab pertanyaan dari teman dan gaya bahasa formal yang digunakan. Penilaian aspek keterampilan literasi tersebut diberikan melalui soal pada akhir pembelajaran kemudian dinilai sesuai rubrik yang telah di sediakan.

Aspek sikap siswa diperoleh melalui data hasil pengamatan terhadap sikap yang muncul pada siswa selama kegiatan pembelajaran berlangsung. Sikap yang diamati meliputi sikap spiritual dan sikap literasi sains. Sikap spiritual dengan menuliskan hal yang dirasakan tentang kebesaran Alloh dalam video proses fotosintesis dan menuliskan tindakan yang 
akan dilakukan selanjutnya terhadap lingkungan maupun terhadap diri sendiri.

Sikap literasi yang diamati ada 2, yaitu: (1) menunjukkan minat terhadap ilmu pengetahuan; (2) mendukung penemuan ilmiah. Indikator menunjukkan minat terhadap ilmu pengetahuan, yaitu: (a) hati-hati dalam mengukur bahan praktikum; (b) mengamati hasil percobaan berupa tepung tapioka dengan sesuai prosedur; (c) melakukan praktikum dengan serius dan rasa ingin tahu; (d) rasa ingin tahu dengan bertanya kepada guru apakah data yang diperoleh dan cara menulisnya benar; (e) antusias, aktif dalam dalam kegiatan kelompok praktikum; (f) aktif berperan serta dalam praktikum dengan mengembalikan peralatan yang digunakan dalam praktikum.

Indikator mendukung penemuan ilmiah yaitu: (a) mengamati hasil percobaan sesuai prosedur; (b) antusias membantu teman untuk merapikan area praktikum; (c) mengamati hasil percobaan dengan seksama; (d) antusias meminta temannya yang kurang serius mengerjakan tugas untuk menjadi serius. Sikap literasi yang dapat dinyatakan dalam bentuk jurnal belajar, hal ini dilakukan mengacu pada panduan penilaian hasil belajar untuk SMP oleh Permendikbud nomor 53 tahun 2015.

\section{SIMPULAN DAN SARAN}

\section{A. Simpulan}

Berdasarkan hasil analisis dan pembahasan hasil penelitian pengembangan perangkat dan penerapan pembelajaran model Cooperative Learning untuk melatih literasi sains siswa sekolah menengah pertama, diperoleh temuan sebagai berikut:

1. Validitas perangkat pembelajaran model Cooperative Learning untuk melatih literasi sains siswa yang telah dikembangkan dinyatakan sangat valid dan dapat digunakan dalam kegiatan pembelajaran IPA di SMP.

2. Kepraktisan perangkat pembelajaran model Cooperative Learning yang dikembangkan dilihat dari 2 aspek sebagai berikut: a) Keterlaksanaan rencana pelaksanaan pembelajaran selama proses pembelajaran dengan rata-rata keseluruhan skor keterlaksanaannya dikategorikan sangat baik. b) Kendala yang dihadapi pada uji coba II antara lain terkait dengan masalah manajemen waktu.
Namun dapat diperbaiki pada pertemuan selanjutnya, sehingga secara umum pembelajaran berjalan dengan baik.

3. Keefektifan perangkat pembelajaran model Cooperative Learning yang dikembangkan dapat dilihat dari 2 aspek sebagai berikut: a) Penerapan perangkat pembelajaran dapat mengembangkan aspek sikap siswa. Hasil belajar aspek sikap spiritual dan sikap literasi dilakukan siswa dengan baik. b) Penerapan perangkat pembelajaran model Cooperative Learning dapat melatih literasi sains siswa aspek pengetahuan/conten dan aspek konteks literasi. c) Pembelajaran model Cooperative Learning mendapatkan respons positif dari siswa dengan persentase $82,70 \%$.

\section{B. Saran}

Berdasarkan hasil penelitian pengembangan perangkat pembelajaran yang telah dilakukan, terdapat beberapa saran antara lain: Pengembangan perangkat pembelajaran model Cooperative Learning dapat melatih literasi sains siswa sehingga perlu dikembangkan secara lebih luas pada materi pembelajaran IPA lainnya sehingga literasi sains siswa semakin terlatih. Peneliti-peneliti selanjutnya dapat melatih siswa untuk lebih mengembangkan literasi sains dengan indikator lainnya pada pembelajaran IPA dan mata pelajaran lainnya.

Guru perlu mengajak siswa untuk selalu terlibat dengan informasi dan kegiatan pembelajaran mengenai lingkungan, tehnologi sehingga dapat memperluas wawasan siswa dan menimbulkan kepedulian lingkungan. Komponen literasi sain yang masih belum dikuasai oleh beberapa siswa perlu dilatihkan lagi sehingga semua siswa dapat mencapai nilai yang optimal.

Perlu adanya penilaian secara tersendiri untuk mencantumkan keterampilan literasi sains karena literasi sains memuat banyak komponen yang harus diberi penilaian.

\section{DAFTAR PUSTAKA}

Arisman, A dan Permanasari, A. 2015. Penerapan Pembelajaran Kooperatif Tipe STAD dengan Metode Praktikum dan Demonstrasi Multimedia Interaktif (MMI) dalam Pembelajaran IPA Terpadu untuk Meningkatkan Literasi Sains Siswa. Pendidikan Ilmu Pengetahuan Alam Sekolah 
Pascasarjana Universitas Pendidikan Indonesia, Bandung. Journal.uinjkt.ac.id/index.php/edusains. EDUSAINS, 7 (2), 2015, 179-184

Borich, G. D. (2015). Observation Skills for Effective Teaching Research-Based Practice ( $7^{\text {th }}$ ed.). New York: Routledge.

Bybee, R. W., 2009. PISA'S 2006 Measurement of Scientific Literacy: An Insider's Perspective for the U.S. A Presentation for the NCES PISA Research Conference.Washington: Science Forum and Science Expert Group

Cansiz, Mustafa and Nurcan, Turkey. 2011. Scientific Literacyn Investigation In Science Curricula: The Case Of Turkey. Special Issue: Selected Papers presented at WCNTSE: Western Anatolia Journal of Educational Science. ISSN 1308-8971

Carrier, K. A. 2005. Supporting Science Leteracy Objectives for Learning through Science English Language Learners. Juornal of Science Activity.

Groundlund, A. E., \& Linn, R. L. (1995). Measurement and Evaluation in Teaching. New York: McMilan Publishing Company.

Hahn, Inga. 2013. Assesing scientific literacy over the lifespan - A description of the NEPS science framework and the test development. Education Research Online. Juornal for Building for schung Online Volume 5(2013), No. 2, 110-138.

Huda, Miftahul 2011. Cooperative Learning Metode, Teknik, Struktur dan Penerapan.Yogyakarta : Pustaka Pelajar.

Holbrook, J. \& Milia R. 2009. "The Meaning of Scientific Literacy". International Journal of Environmental \& Science Educational, 4 (3), 144-150.

Jack Holbrook. 2011. Enhancing Scientific and Technological Literacy (STL): A Major Focus for Science Teaching at School.

Kose, S., Sahin, A., Ergun, A., \& Gezer, K. (2010). The Effects of Cooperative Learning Experience on Eighth Grade Students' Achievement and Attitude toward Science. Journal Education, 131(1), 169-180.

OECD. 2009. The PISA 2009 Assesment Framework: Mathematics, reading science and problem solving knowledge and skills, Paris,

URL https://www.pisa.oecd.org/data oecd/38/51/33707192.pdf, (Diakses 09 November 2014).

OECD , 2010, PISA 2009 Results: What Students Know and Can Do - Student Performance in Reading, Mathematics and Science (Volume I),

http://dx.doi.org/10.1787/9789264091450en (26 Februari 2013).

OECD-PISA. 2013. Sciencetific Literacy Framewrok. 2013.

Slavin, R. E. 2007. Cooperative Learning Theory, Research, and Practice. $2^{\text {nd }}$ Ed. London: Allyn and Bacon. 